University of Nebraska - Lincoln

DigitalCommons@University of Nebraska - Lincoln

U.S. Department of Justice Publications and Materials

U.S. Department of Justice

$10-2009$

\title{
Profile of Intimate Partner Violence Cases in Large Urban Counties
}

Erica L. Smith

BJS Statistician

Donald J. Farole Jr.

BJS Statistician

Follow this and additional works at: https://digitalcommons.unl.edu/usjusticematls

Smith, Erica L. and Farole, Donald J. Jr., "Profile of Intimate Partner Violence Cases in Large Urban Counties" (2009). U.S. Department of Justice Publications and Materials. 5.

https://digitalcommons.unl.edu/usjusticematls/5

This Article is brought to you for free and open access by the U.S. Department of Justice at DigitalCommons@University of Nebraska - Lincoln. It has been accepted for inclusion in U.S. Department of Justice Publications and Materials by an authorized administrator of DigitalCommons@University of Nebraska - Lincoln. 


\section{Bureau of Justice Statistics}

\section{State Court Processing Statistics}

\section{Profile of Intimate Partner Violence Cases in Large Urban Counties}

Erica L. Smith and Donald J. Farole, Jr., Ph.D. BJS Statisticians

I $n$ the state courts of 16 large urban counties, 3,750 cases of intimate partner violence (IPV) were filed in May 2002. These cases represent $83 \%$ of the 4,562 domestic violence cases filed in the 16 counties. ${ }^{1}$ A case was defined as intimate partner violence if it involved an allegation of intentional physical violence committed, attempted, or threatened between spouses, ex-spouses, common-law spouses, boyfriends or girlfriends, present or past. For more information on the definitions of domestic violence and intimate partner violence used in this report, see the Methodology.

More than half of IPV defendants were convicted, and of those convicted, more than $80 \%$ were sentenced to incarceration in either prison or jail. This report examines the case characteristics that are associated with an increased likelihood of conviction.

\footnotetext{
${ }^{1}$ See appendix table 1 for distribution of victim-offender rela-
} tionships for all 4,562 domestic violence cases in the study.
This report is based on data collected in the study Processing of Domestic Violence Cases in State Courts, conducted by the Bureau of Justice Statistics (BJS). Findings are based on information documented in prosecutor files and court records of 3,750 intimate partner violence cases. Cases were tracked for one year following the defendant's first court appearance in May 2002.

\section{Most cases of intimate partner violence involved a female victim and a male defendant}

Victims in intimate partner violence cases were generally female $(86 \%)$, while defendants were generally male (86\%) (table 1$)$. The majority of IPV cases (84\%) involved a male defendant and a female victim. Twelve percent of cases involved a female defendant and a male victim (not shown in table). In $4 \%$ of IPV cases, the defendant and victim were of the same gender.

\section{Highlights}

Among 3,750 cases of intimate partner violence filed in the state courts of 16 large urban counties in May 2002:

- Most involved a female victim and a male defendant (84\%).

- Most involved a charge of assault, either aggravated (12\%) or simple (78\%); an additional 5\% were charged with intimidation, including stalking.

- Nearly half (46\%) involved a defendant with a prior history of abuse toward the same victim.

- Approximately 1 in 4 cases involved the use of a weapon, such as a gun, a knife, or other blunt object.
- Defendants charged with a felony (44\%) were twice as likely to have used a weapon as defendants charged with a misdemeanor $(22 \%)$.

- A witness to the incident was present in nearly half of intimate partner violence cases; half of those witnesses were children.

- A history of abuse between the victim and defendant, among other characteristics, was associated with a higher likelihood that the case resulted in a conviction. 


\section{Table 1.}

Demographic characteristics of intimate partner violence victims and defendants in 16 large counties, May 2002

\begin{tabular}{l|c|c}
\hline \multirow{2}{*}{ Demographic characteristic } & \multicolumn{2}{c}{ Percent of intimate partner violence- } \\
\hline \multicolumn{1}{|c|}{ Total } & Victims & Defendants \\
\hline Gender & $100 \%$ & $\mathbf{1 0 0 \%}$ \\
\hline Male & $14.0 \%$ & 13.7 \\
\hline Female & 86.0 & \\
\hline Race/Hispanic origin & & $33.6 \%$ \\
\hline White non-Hispanic & $37.1 \%$ & 33.5 \\
\hline Black non-Hispanic & 26.4 & 30.8 \\
\hline Hispanic & 33.6 & 2.0 \\
\hline Other non-Hispanic & 2.8 & \\
\hline Age at offense & & $0.2 \%$ \\
\hline 17 or younger & $2.7 \%$ & 24.2 \\
\hline $18-24$ & 26.1 & 34.8 \\
\hline $25-34$ & 34.9 & 38.2 \\
\hline $35-54$ & 34.0 & 2.6 \\
\hline 55 or older & 2.3 & \\
\hline
\end{tabular}

Note: Among the 3,750 cases of intimate partner violence, data on a defendant's gender were reported for $99.4 \%$; race/Hispanic origin for $85.6 \%$; age for $99.2 \%$. Data on a victim's gender were reported for $100 \%$ of cases; race/Hispanic origin for $94.5 \%$; age for $94.4 \%$.

\section{Table 2.}

Most serious charges filed against intimate partner violence defendants in 16 large counties, by charge type, May 2002

\begin{tabular}{|c|c|c|c|}
\hline \multirow[b]{2}{*}{ Most serious arrest charge } & \multirow[b]{2}{*}{ All cases } & \multicolumn{2}{|c|}{ Percent of defendants charged with a- } \\
\hline & & Felony & Misdemeanor \\
\hline Total & $100 \%$ & $100 \%$ & $100 \%$ \\
\hline Murder & 0.2 & 1.0 & -- \\
\hline Rape/sexual assault & 1.7 & 8.5 & 0.2 \\
\hline Robbery & 0.2 & 1.3 & -- \\
\hline Aggravated assault & 12.2 & 66.1 & -- \\
\hline Simple assault & 77.9 & -- & 95.6 \\
\hline Intimidation $^{\mathrm{a}}$ & 4.9 & 10.1 & 3.7 \\
\hline Other violent offense $^{b}$ & 2.8 & 13.0 & 0.5 \\
\hline Total cases & 3,750 & 693 & 3,057 \\
\hline
\end{tabular}

Note: Aggravated assault is defined as felony assault. Simple assault is defined as misdemeanor assault. --No cases reported.

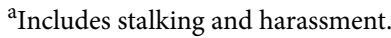

${ }^{\mathrm{b}}$ Includes offenses such as kidnapping and false imprisonment/criminal confinement.
IPV victims and defendants had similar race and ethnic profiles. Roughly equal percentages of victims and defendants were white, black, and Hispanic. This was comparable to the distribution of race and Hispanic origin across all violent felony defendants in the 16 counties in $2002 .^{2}$

Fifty-nine percent of defendants and $58 \%$ of victims in IPV cases were between the ages of 18 and 34 at the time of the incident. Intimate partner violence involving victims age 55 or older accounted for less than $3 \%$ of cases. Because these cases were processed in adult courts, very few defendants $(0.2 \%)$ were under age 18 .

\section{The majority of IPV defendants were} charged with a misdemeanor

A misdemeanor was the most serious charge filed against the majority of defendants in intimate partner violence cases. Most misdemeanor charges (96\%) were for simple assault (table 2). Intimidation made up most of the remaining misdemeanor IPV charges.

Aggravated assault made up two-thirds (66\%) of felony IPV charges. About $9 \%$ of felony IPV charges were for rape or sexual assault and about $1 \%$ were for murder. Together, 9 in 10 defendants in intimate partner violence cases were charged with either simple $(78 \%)$ or aggravated $(12 \%)$ assault.

\section{Most intimate partner violence incidents occurred in the victim's residence}

Prosecutor files indicated that $58 \%$ of IPV incidents occurred in a residence shared by the victim and defendant (table 3). Another $21 \%$ of IPV incidents occurred in a residence occupied by the victim, but not by the defendant. A greater percentage of misdemeanor (60\%) than felony cases $(49 \%)$ arose from incidents that occurred in a shared residence. Less than $2 \%$ of felony or misdemeanor cases occurred in the workplace.

${ }^{2}$ See Felony Defendants in Large Urban Counties, 2002, February 2006, NCJ 210818, available at http:// www.ojp.usdoj.gov/bjs/abstract/fdluc02.htm. (Last accessed September 24, 2009.) 
A third of defendants in intimate partner violence cases were using alcohol or drugs

Thirty-three percent (33\%) of defendants in IPV cases were using alcohol or drugs at the time of the incident. The percentage did not vary by whether a defendant was charged with a felony or a misdemeanor (table 4).

The majority of defendants using alcohol or drugs at the time of the incident were under the influence of alcohol only. Defendants charged with a felony (28\%) IPV were as likely as defendants charged with a misdemeanor (29\%) to have been under the influence of alcohol.

\section{Defendants used a weapon in 1 in 4} intimate partner violence cases

A weapon was used by the defendant in $26 \%$ of IPV cases (table 5). Felony IPV (44\%) was more likely to be characterized by weapon use than misdemeanor IPV (22\%). About $6 \%$ of the defendants charged with a felony used a firearm, while about $15 \%$ used a knife or other sharp object.

Female defendants (41\%) were more likely than male defendants $(24 \%)$ to use a weapon during an incident of intimate partner violence (not shown in table). Additionally, female defendants $(12 \%)$ were twice as likely as male defendants (5\%) to use a knife or sharp object, and three times more likely (17\%) than male defendants $(6 \%)$ to use a blunt object such as a pipe or rock during an IPV incident.

Prosecutor files indicated that about three-quarters $(74 \%)$ of IPV defendants did not use a weapon. These include cases in which defendants may have used hands, fists, or feet as a personal weapon.

\section{Table 3.}

Location of incident in intimate partner violence cases in 16 large counties, by charge type, May 2002

\begin{tabular}{|c|c|c|c|}
\hline \multirow[b]{2}{*}{ Location of incident } & \multirow[b]{2}{*}{ All cases } & \multicolumn{2}{|c|}{ Percent of defendants charged with a- } \\
\hline & & Felony & Misdemeanor \\
\hline Total & $100 \%$ & $100 \%$ & $100 \%$ \\
\hline Residential & 85.0 & 83.8 & 85.3 \\
\hline Residence shared by victim and defendant & 58.1 & 48.9 & 60.2 \\
\hline Victim's residence & 21.1 & 25.3 & 20.2 \\
\hline Defendant's residence & 4.2 & 7.5 & 3.4 \\
\hline Other residence $^{\mathrm{a}}$ & 1.6 & 1.9 & 1.6 \\
\hline Victim or defendant's workplace & 1.2 & 1.6 & 1.1 \\
\hline Private or public vehicle & 7.0 & 8.8 & 6.6 \\
\hline Public place & 5.9 & 4.5 & 6.2 \\
\hline Other location $^{\text {D }}$ & 1.0 & 1.2 & 0.9 \\
\hline Total cases $^{\mathrm{c}}$ & 3,717 & 683 & 3,034 \\
\hline \multicolumn{4}{|c|}{${ }^{\mathrm{a}}$ Includes incidents that occurred at the home of a relative or a friend. } \\
\hline \multicolumn{4}{|c|}{$\begin{array}{l}\mathrm{b}^{\mathrm{b}} \text { Includes incidents that occurred in a hotel or motel room, at a shelter, or threats made over the } \\
\text { telephone. }\end{array}$} \\
\hline \multicolumn{4}{|c|}{${ }^{\mathrm{c}}$ Excludes cases for which the location of incident was not reported. } \\
\hline
\end{tabular}

\section{Table 4.}

Alcohol and drug use among defendants in intimate partner violence cases in 16 large counties, by charge type, May 2002

\begin{tabular}{l|c|c|c}
\hline \multirow{2}{*}{$\begin{array}{l}\text { Alcohol or drug use } \\
\text { Total }\end{array}$} & All cases & \multicolumn{2}{|c}{ Percent of defendants charged with a- } \\
\cline { 3 - 4 } & $\mathbf{1 0 0 \%}$ & $\mathbf{1 0 0} \%$ & Misdemeanor \\
\hline $\begin{array}{l}\text { Defendant was using alcohol or } \\
\text { drugs at the time of the incident }\end{array}$ & 32.8 & 32.9 & $\mathbf{1 0 0 \%}$ \\
\hline Alcohol only & 28.6 & 28.0 & 32.7 \\
\hline Drugs only & 1.8 & 2.5 & 28.7 \\
\hline Alcohol and drugs & 1.0 & 1.7 & 1.6 \\
\hline Other substance & 1.4 & 0.7 & 1.6 \\
\hline $\begin{array}{l}\text { Defendant was not using alcohol or } \\
\text { drugs at the time of the incident }\end{array}$ & $\mathbf{6 7 . 2}$ & 67.1 & 67.3 \\
\hline Total cases & $\mathbf{3 , 7 5 0}$ & $\mathbf{6 9 3}$ & $\mathbf{3 , 0 5 7}$ \\
\hline${ }^{*}$ Includes unknown substances. & & & \\
\hline
\end{tabular}

\section{Table 5.}

Weapon use among defendants in intimate partner violence cases in 16 large counties, by charge type, May 2002

\begin{tabular}{|c|c|c|c|}
\hline \multirow[b]{2}{*}{ Weapon use } & \multirow[b]{2}{*}{ All cases } & \multicolumn{2}{|c|}{ Percent of defendants charged with a- } \\
\hline & & Felony & Misdemeanor \\
\hline Total & $100 \%$ & $100 \%$ & $100 \%$ \\
\hline $\begin{array}{l}\text { Primary weapon defendant used } \\
\text { during the incident }\end{array}$ & 26.0 & 44.1 & 21.9 \\
\hline Firearm & 2.0 & 6.2 & 1.0 \\
\hline Knife/sharp object & 5.8 & 14.5 & 3.9 \\
\hline Hard object/wall & 5.7 & 8.8 & 4.9 \\
\hline Blunt object & 7.1 & 8.4 & 6.9 \\
\hline Other weapon ${ }^{\star}$ & 3.1 & 3.3 & 3.1 \\
\hline Unknown weapon & 2.3 & 2.8 & 2.2 \\
\hline Defendant did not use a weapon & 74.0 & 55.9 & 78.1 \\
\hline Total cases & 3,750 & 693 & 3,057 \\
\hline
\end{tabular}




\section{Table 6.}

Most severe injury to victim in intimate partner violence cases in 16 large counties, by charge type, May 2002

\begin{tabular}{|c|c|c|c|}
\hline \multirow[b]{2}{*}{ Type of injury } & \multirow[b]{2}{*}{ All cases } & \multicolumn{2}{|c|}{ Percent of defendants charged with a- } \\
\hline & & Felony & Misdemeanor \\
\hline Total & $100 \%$ & $100 \%$ & $100 \%$ \\
\hline Any injury & 89.2 & 86.0 & 90.0 \\
\hline More severe injury & 8.6 & 22.8 & 5.4 \\
\hline Gunshot/stab wound & 0.7 & 2.6 & 0.2 \\
\hline Rape/sexual assault & 1.7 & 8.3 & 0.2 \\
\hline Severe lacerations/burns & 4.8 & 8.7 & 4.0 \\
\hline Other major injury $^{\mathrm{a}}$ & 1.4 & 3.2 & 1.0 \\
\hline Less severe injury ${ }^{\mathrm{b}}$ & 60.7 & 45.3 & 64.2 \\
\hline Unknown injury & 19.9 & 17.9 & 20.3 \\
\hline Not injured/unknown & 10.8 & 14.0 & 10.0 \\
\hline Total cases & 3,750 & 693 & 3,057 \\
\hline
\end{tabular}

\section{Table 7.}

Witness to the incident in intimate partner violence cases in 16 large counties, by charge type, May 2002

\begin{tabular}{l|c|c|c}
\hline & & \multicolumn{2}{|c}{ Percent of defendants charged with a- } \\
\cline { 3 - 4 } Presence of witness & All cases & Felony & Misdemeanor \\
\hline Total & $\mathbf{1 0 0 \%}$ & $\mathbf{1 0 0 \%}$ & $\mathbf{1 0 0 \%}$ \\
\hline Witness to the incident & 49.9 & 53.8 & 49.0 \\
\hline Direct/eyewitness & 43.0 & 45.0 & 42.5 \\
\hline Indirect witness & 8.1 & 9.2 & 7.9 \\
\hline No witness to the incident & 50.1 & 46.2 & 51.0 \\
\hline Total cases & $\mathbf{3 , 7 5 0}$ & $\mathbf{6 9 3}$ & $\mathbf{3 , 0 5 7}$ \\
\hline
\end{tabular}

Note: Percents do not sum to $100 \%$ because prosecutorial files may indicate both direct and indirect witnesses to the incident.

*Includes individuals with knowledge of the incident but did not visually witness the incident.

\section{Table 8.}

Children present during the incident in intimate partner violence cases in 16 large counties, by charge type, May 2002

\begin{tabular}{l|c|c|c}
\hline \multirow{2}{*}{ Presence of children } & & \multicolumn{2}{|c}{ Percent of defendants charged with a- } \\
\cline { 3 - 4 } Total & All cases & Felony & Misdemeanor \\
\hline Child was present during incident & $\mathbf{1 0 0 \%}$ & $\mathbf{1 0 0} \%$ & $\mathbf{1 0 0 \%}$ \\
\hline Child witnessed violence & 36.4 & 36.9 & 36.3 \\
\hline Child did not witness violence & 22.0 & 22.7 & 21.8 \\
\hline Child not present during incident & 14.4 & 14.3 & 14.5 \\
\hline Total cases & 63.6 & 63.1 & 63.7 \\
\hline
\end{tabular}

Nearly 9 in 10 victims of IPV sustained an injury during the incident; about 1 in 10 suffered a severe injury

Eighty-nine percent of IPV victims were injured as a result of the incident (table 6). Most victims sustained injuries that were of a less severe nature, such as minor cuts, redness, bruises, and complaints of pain. Nine percent of victims sustained more severe injuries, including gunshot and stab wounds, rape or sexual assault, severe lacerations, and broken bones.

The overall prevalence of any victim injury was comparable between felony and misdemeanor cases; however, victims of felony IPV (23\%) were more likely than victims of misdemeanor IPV (5\%) to suffer more severe injuries. Nearly $3 \%$ of all felony IPV victims suffered a gunshot or a stab wound, $8 \%$ were raped or sexually assaulted, and $9 \%$ suffered severe lacerations or burns.

A direct witness was present in more than $40 \%$ of intimate partner violence cases; half of those witnesses were children

Half of intimate partner violence cases were witnessed by a third party (table 7 ). The majority of those witnesses were direct eyewitnesses to the violence.

Children were witnesses to the violence in $22 \%$ of IPV cases (table 8). These child witnesses accounted for half of the direct eyewitnesses to the violence (not shown in table). In another $14 \%$ of IPV cases, a child was present at the time of the incident, but did not directly witness the violence. 
Physical evidence was obtained in about 7 in 10 intimate partner violence cases

Physical evidence, such as photos, tapes of the 911 call, and forensic evidence, was obtained in $68 \%$ of IPV cases (table 9). Photographic evidence and the tape of a 911 call were the most common forms of physical evidence obtained. Physical evidence was obtained in a higher percentage of felony $(75 \%)$ than misdemeanor $(66 \%)$ cases.

The types of evidence obtained differed slightly between felony and misdemeanor IPV cases. Prosecutor files were more likely to indicate that forensic evidence had been obtained in felony intimate partner violence cases $(10 \%)$ than in misdemeanor IPV cases (2\%). Felony cases were also more likely to result in a weapon being recovered $(11 \%)$ and medical records being obtained (10\%) than misdemeanor IPV cases.

In addition to physical evidence, a statement was obtained from a witness to the incident in just under half of IPV cases. Felony cases were more likely than misdemeanor cases to feature a witness statement. In about 1 in 10 cases of IPV, the prosecution obtained a statement from the defendant.

\section{Nearly 1 in 4 intimate partner violence} victims had reported prior violence by the same defendant to police

One factor known to affect outcomes in criminal cases is a defendant's prior criminal history. While the survey did not collect information on a defendant's entire criminal history, two measures of prior domestic violence were documented from information recorded in prosecutor files: 1) history of abuse between the victim and the defendant in the case, and 2) whether the victim reported any prior violence to the police.

Forty-six percent of intimate partner violence cases involved a defendant with a prior history of abuse toward the same victim, and $24 \%$ of victims of IPV had reported prior violence to police (table 10). These percentages were similar for both felony and misdemeanor IPV.

\section{Table 9.}

Evidence obtained in intimate partner violence cases in 16 large counties, by charge type, May 2002

\begin{tabular}{l|c|c|c}
\hline \multirow{2}{*}{ Type of evidence } & & \multicolumn{2}{|c}{ Percent of defendants charged with a- } \\
\cline { 3 - 4 } & All cases & Felony & Misdemeanor \\
\hline Total & $\mathbf{1 0 0 \%}$ & $\mathbf{1 0 0} \%$ & $\mathbf{1 0 0 \%}$ \\
\hline Any evidence obtained & 83.5 & 90.9 & 81.8 \\
\hline Physical evidence & 67.9 & 74.9 & 66.3 \\
\hline Photos of victim/defendant & 46.5 & 44.9 & 46.9 \\
\hline Tape of 911 call & 25.9 & 30.4 & 24.9 \\
\hline Photos of scene & 12.2 & 19.8 & 10.5 \\
\hline Weapon recovered & 4.7 & 10.7 & 3.3 \\
\hline Medical records & 3.4 & 10.4 & 1.8 \\
\hline Forensic evidence & 3.3 & 9.8 & 1.8 \\
\hline Other evidence & 8.3 & 11.3 & 7.7 \\
\hline Statement from witness & 45.9 & 58.0 & 43.1 \\
\hline Statement from defendant & 10.2 & 12.7 & 9.7 \\
\hline No evidence obtained & 16.5 & 9.1 & 18.2 \\
\hline Total cases & $\mathbf{3 , 7 5 0}$ & $\mathbf{6 9 3}$ & $\mathbf{3 . 0 5 7}$ \\
\hline
\end{tabular}

Note: Detail does not sum to total because more than one type of evidence was obtained in some cases.

\section{Table 10.}

History and reporting of prior violence between victim and defendant in intimate partner violence cases in 16 large counties, by charge type, May 2002

\begin{tabular}{l|c|c|c}
\hline & & \multicolumn{2}{|c}{ Defendants charged with a- } \\
\cline { 3 - 4 } Percent of cases in which- & All cases & Felony & Misdemeanor \\
\hline $\begin{array}{l}\text { There was a history of abuse between } \\
\text { victim and defendant }\end{array}$ & $46.3 \%$ & $46.6 \%$ & $46.3 \%$ \\
\hline $\begin{array}{l}\text { Victim reported prior violence by } \\
\text { defendant to police }\end{array}$ & 23.5 & 26.1 & 22.9 \\
\hline \begin{tabular}{l} 
Total cases \\
\hline
\end{tabular}
\end{tabular}


Most convictions for intimate partner violence were for a misdemeanor charge

Fifty-six percent of intimate partner violence cases filed with the court in the 16 participating counties resulted in a conviction (table 11). Most of those convictions were for a misdemeanor. A third (33\%) of the cases were discontinued by the prosecution or dismissed by the court; less than $1 \%$ ended in acquittal. Another $9 \%$ of defendants were in a pretrial diversion or deferred adjudication status one year after their initial appearance. $^{3}$

\section{Table 11.}

Adjudication outcome in intimate partner violence cases in 16 large counties, by charge type, May 2002

\begin{tabular}{|c|c|c|c|}
\hline \multirow[b]{2}{*}{ Adjudication outcome } & \multirow[b]{2}{*}{ All cases } & \multicolumn{2}{|c|}{ Percent of defendants charged with a- } \\
\hline & & Felony & Misdemeanor \\
\hline Total & $100 \%$ & $100 \%$ & $100 \%$ \\
\hline Convicted & 56.0 & 60.5 & 54.9 \\
\hline Felony & 9.0 & 46.5 & 0.4 \\
\hline Misdemeanor & 45.6 & 13.7 & 52.8 \\
\hline Unknown & 1.4 & 0.3 & 1.7 \\
\hline Dismissal/nolle prosequi & 33.0 & 31.4 & 33.4 \\
\hline Acquittal & 0.6 & 0.9 & 0.6 \\
\hline $\begin{array}{l}\text { Pretrial diversion or deferred } \\
\text { adjudication }\end{array}$ & 8.6 & 5.6 & 9.3 \\
\hline Case pending $^{a}$ & 1.8 & 1.6 & 1.8 \\
\hline Total cases $^{\mathrm{D}}$ & 3,729 & 685 & 3,044 \\
\hline $\begin{array}{l}{ }^{\mathrm{a}} \text { As of May 31, } 2003 . \\
{ }^{\mathrm{b}} \text { Excludes cases for which ad }\end{array}$ & omes $\mathrm{V}$ & vailable. & \\
\hline
\end{tabular}

\section{Table 12.}

Most severe sentence imposed on convicted defendants in 16 large counties, by conviction charge, May 2002

\begin{tabular}{|c|c|c|c|}
\hline \multirow[b]{2}{*}{ Most severe sentence } & \multirow[b]{2}{*}{ All cases ${ }^{a}$} & \multicolumn{2}{|c|}{ Percent of defendants charged with a- } \\
\hline & & Felony & Misdemeanor \\
\hline Total & $100 \%$ & $100 \%$ & $100 \%$ \\
\hline Prison & 7.4 & 43.9 & 0.2 \\
\hline Jail & 75.3 & 46.4 & 81.2 \\
\hline Probation & 17.3 & 9.7 & 18.7 \\
\hline Total cases $^{b}$ & 2,010 & 330 & 1,630 \\
\hline
\end{tabular}

Note: Table excludes cases pending as of May 31, 2003.

${ }^{a}$ Includes cases for which a conviction charge was unknown.

${ }^{b}$ Excludes the $3.6 \%$ of cases that resulted in conviction for which sentencing data were not available.
The percentage of cases filed with the court that led to a conviction varied across the 16 counties, ranging from a low of $17 \%$ to a high of $89 \%$. One factor contributing to differences in conviction rates was the difference in case filing practice utilized by prosecutors in the counties. In 9 of the 16 jurisdictions, prosecutors indicated they generally screened cases to determine whether to pursue a conviction prior to a defendant's initial court appearance. In the remaining seven jurisdictions, the decision whether to pursue a conviction was made after the case was filed in court. The conviction rate was $72 \%$ among the nine jurisdictions that screened cases prior to filing (See Methodology, table 17). Comparatively, $37 \%$ of cases filed led to a conviction in jurisdictions that did not screen before the initial filing. For more information on case screening policies and differences in case outcomes by jurisdiction, see the Methodology.

\section{Most convicted defendants in intimate partner violence cases received a jail sentence}

More than $80 \%$ of defendants convicted in intimate partner violence cases received either a jail $(75 \%)$ or prison (7\%) sentence (table 12). Fortyfour percent of defendants convicted of felony IPV were sentenced to prison for one year or more. A jail sentence was imposed on 4 in 5 defendants convicted of a misdemeanor and on about half of defendants convicted of a felony. About 1 in 5 convicted defendants were not incarcerated, receiving a probation sentence instead.

\section{Cases resulting in a conviction were more} likely to have a third party witness the incident

The characteristics of cases that resulted in a conviction were compared to the characteristics of cases in which prosecution was declined or that resulted in a dismissal or acquittal. Excluded from the analysis were 1) cases that resulted in pretrial diversion or deferred adjudication; 2 ) cases for which the final outcome was unknown; and 3) cases whose outcome was pending as of one year after the initial court filing. A total of 409 cases were excluded from the analysis.

\footnotetext{
${ }^{3}$ Cases in pretrial diversion or deferred adjudication status generally have not reached a final adjudication outcome. Many defendants who successfully complete the requirements of a diversion program have their case dismissed. Defendants who do not complete program requirements are generally convicted.
} 
A third party witnessed the incident in more than half (56\%) of the cases that resulted in a conviction, compared to $41 \%$ of cases that were adjudicated by dismissal, acquittal, or nolle prosequi (table 13). The prosecution obtained physical evidence and a statement by the defendant in a slightly larger percentage of cases that resulted in conviction than those that did not. Cases that led to a conviction were also more likely to have a history of abuse between the victim and the defendant, as well as a child present at the time of the incident. A somewhat higher percentage of convicted defendants were using alcohol or drugs at the time of the incident, compared to defendants who were not convicted.

\section{Cases in which the defendant made a}

formal statement were twice as likely to result in conviction

The survey collected information about the characteristics of intimate partner violence cases that may influence the likelihood that a case will result in conviction. Logistic regression analysis was used to assess the unique contribution of various case characteristics to the probability of conviction (table 14). The analysis produced estimates of the association between each independent variable (the case characteristics) and the dependent variable (the likelihood of conviction). See the Methodology for more information about logistic regression techniques.

In general the logistic regression analysis yielded patterns of influence on the probability of conviction similar to that of the bivariate results. The presence of a statement from the defendant was the case characteristic with the greatest impact on the likelihood of conviction. The odds ratio indicated that cases in which prosecutors obtained a statement from the defendant were twice as likely to result in conviction than cases in which there was no statement. Additionally, the presence of a third-party witness to the incident increased the likelihood of conviction by 1.7 times, as did a documented history of abuse between the victim and defendant. Whether physical evidence was obtained was also positively, although less strongly, associated with the likelihood of a conviction. Other case characteristics, such as whether a child was present at the time of the incident and whether the defendant used a weapon, had little independent impact on the probability of a conviction. ${ }^{4}$

\footnotetext{
${ }^{4}$ Other factors potentially related to the probability of conviction were also included in the logistic regression model but are not reported in table 14. See the Methodology for more detail.
}

\section{Table 13.}

Characteristics of intimate partner violence cases in 16 large counties, by adjudication outcome, May 2002

\begin{tabular}{|c|c|c|c|c|}
\hline \multirow[b]{3}{*}{ Case characteristics } & \multicolumn{4}{|c|}{ Adjudication outcome } \\
\hline & \multirow[b]{2}{*}{$\begin{array}{l}\text { Dismissal/acquittal/ } \\
\text { nolle prosequi }\end{array}$} & \multicolumn{3}{|c|}{ Conviction } \\
\hline & & Any conviction ${ }^{\mathbf{a}}$ & Felony & Misdemeanor \\
\hline \multicolumn{5}{|l|}{ Incident characteristics } \\
\hline Defendant used alcohol or drugs & $29.0 \%$ & $34.7 \%$ & $34.1 \%$ & $35.1 \%$ \\
\hline Child present at time of incident & 30.8 & 40.1 & 38.6 & 40.3 \\
\hline Weapon used in incident & 25.7 & 26.7 & 46.1 & 23.1 \\
\hline Victim injured in incident & 91.6 & 90.6 & 78.7 & 92.7 \\
\hline Witness to the incident & 40.6 & 56.4 & 59.9 & 55.9 \\
\hline Direct/eyewitness & 36.7 & 47.0 & 47.0 & 47.0 \\
\hline Indirect witness & 4.2 & 11.2 & 13.5 & 11.1 \\
\hline \multicolumn{5}{|l|}{ Prior history } \\
\hline $\begin{array}{l}\text { History of abuse between victim } \\
\text { and defendant }\end{array}$ & $40.4 \%$ & $51.9 \%$ & $53.3 \%$ & $52.1 \%$ \\
\hline $\begin{array}{l}\text { Victim reported prior violence } \\
\text { by defendant to police }\end{array}$ & 24.1 & 24.9 & 28.7 & 24.5 \\
\hline \multicolumn{5}{|l|}{ Evidence obtained } \\
\hline Any physical evidence obtained & $63.4 \%$ & $70.6 \%$ & $81.4 \%$ & $68.5 \%$ \\
\hline Statement from witness & 44.9 & 45.3 & 57.2 & 43.0 \\
\hline Statement from defendant & 5.5 & 13.1 & 18.6 & 12.1 \\
\hline Total cases $^{\mathrm{D}}$ & 1,255 & 2,086 & 334 & 1,699 \\
\hline
\end{tabular}

\section{Table 14.}

Logistic regression analysis of the effect of case characteristics on the probability of conviction in intimate partner violence cases in 16 large counties, May 2002

\begin{tabular}{l|c}
\hline Case characteristics & Odds ratio $^{\star}$ \\
\hline Statement from defendant & 2.04 \\
\hline Witness to the incident & 1.73 \\
\hline History of abuse & 1.69 \\
\hline Physical evidence obtained & 1.54 \\
\hline Victim injured in incident & 1.28 \\
\hline Defendant using drugs/alcohol at time of incident & 1.11 \\
\hline Statement from victim & 1.05 \\
\hline Child present at time of incident & 1.01 \\
\hline Weapon used in incident & 0.99 \\
\hline
\end{tabular}

Note: Table presents the results of a logistic regression analysis with the dependent variable indicating the predicted probability that any conviction was obtained. A total of 3,341 cases were included in the logistic regression analysis. Excluded from the analysis were all cases that resulted in pretrial diversion or deferred adjudication, cases with an unknown adjudication outcome, and cases pending as of May 31,2003 . Also excluded from the analysis were cases for which data were unavailable for one or more variables included in the statistical model. Other variables potentially related to the probability of conviction were also included in the logistic regression analysis. These included defendant race and gender, whether the defendant was charged with a felony or misdemeanor, and a variable that accounted for individual county-level effects. See the Methodology for more detail.

${ }^{*}$ An odds ratio greater than 1 indicates that the variable is associated with an increased likelihood that the case resulted in conviction. Variables with larger odds ratios have a larger effect on the probability of conviction than variables with smaller odds ratios. 
About 1 in 8 intimate partner violence cases involved a female defendant and male victim; another 1 in 20 involved a defendant and victim of the same gender

Some case characteristics differed based on the gender of the defendant and victim. Cases with male defendants and female victims were more likely than others to entail a history of abuse between victim and defendant (table 15). A child was also more likely to have witnessed the violence in these cases. Defendant weapon use was more prevalent in cases with female defendants and male victims than in other cases.

A larger percentage of cases with male defendants and female victims resulted in conviction than cases with female defendants and male victims or same-gender cases (table 16). Female defendants convicted of IPV against male defendants were relatively less likely to receive an incarceration sentence.

\section{Table 15.}

Incident characteristics of intimate partner violence cases in 16 large counties, by defendant and victim gender, May 2002

\begin{tabular}{l|c|c|c}
\hline & \multicolumn{2}{|c}{ Intimate partner violence cases involving a- } \\
\cline { 2 - 3 } Incident characteristic & $\begin{array}{l}\text { Male defendant and } \\
\text { female victim }\end{array}$ & $\begin{array}{l}\text { Female defendant and } \\
\text { male victim }\end{array}$ & $\begin{array}{l}\text { Defendant and victim of } \\
\text { same gender }\end{array}$ \\
\hline Percent of cases in which- & & $28.1 \%$ & $34.2 \%$ \\
\hline Defendant was using drugs or alcohol & $33.4 \%$ & 41.3 & 35.6 \\
\hline Weapon was used in incident & 23.2 & 90.2 & 94.5 \\
\hline Victim was injured in incident & 91.0 & 46.7 & 37.7 \\
\hline Witness to the incident & 50.9 & 29.5 & 21.2 \\
\hline Child was present at time of incident & 38.0 & 88.0 & 82.9 \\
\hline Any evidence was obtained & 83.0 & 34.0 & 32.2 \\
\hline $\begin{array}{l}\text { History of abuse existed between victim and } \\
\text { defendant }\end{array}$ & 48.7 & & \\
\hline $\begin{array}{l}\text { Victim reported prior violence by defendant to } \\
\text { police }\end{array}$ & 24.7 & $\mathbf{4 4 1}$ & 16.4 \\
\hline Total cases & $\mathbf{3 , 1 4 0}$ & $\mathbf{1 4 6}$ \\
\hline
\end{tabular}

\section{Table 16.}

Case processing characteristics of intimate partner violence cases in 16 large counties, by defendant and victim gender, May 2002

\begin{tabular}{|c|c|c|c|}
\hline \multirow[b]{2}{*}{ Case processing characteristic } & \multicolumn{3}{|c|}{ Percent of intimate partner violence cases involving a- } \\
\hline & $\begin{array}{l}\text { Male defendant and } \\
\text { female victim }\end{array}$ & $\begin{array}{l}\text { Female defendant and } \\
\text { male victim }\end{array}$ & $\begin{array}{l}\text { Defendant and victim } \\
\text { of same gender }\end{array}$ \\
\hline \multicolumn{4}{|l|}{ Most serious arrest charge } \\
\hline Felony & $19.1 \%$ & $14.5 \%$ & $16.4 \%$ \\
\hline Convicted & $59.8 \%$ & $40.3 \%$ & $43.7 \%$ \\
\hline Felony & 9.9 & 4.9 & 5.6 \\
\hline Misdemeanor & 48.5 & 33.6 & 37.3 \\
\hline Unknown & 1.4 & 1.9 & 0.7 \\
\hline Prison & $7.5 \%$ & $5.0 \%$ & $10.9 \%$ \\
\hline Jail & 76.2 & 65.8 & 67.3 \\
\hline Probation & 16.3 & 29.2 & 21.8 \\
\hline Total cases & 3,140 & 441 & 146 \\
\hline
\end{tabular}




\section{Methodology}

\section{Data Collection}

This report is based on data collected from the study Processing of Domestic Violence Cases in State Courts, conducted by the Bureau of Justice Statistics. Data were collected by the Pretrial Services Resource Center, Washington, D.C., under grant 2002-BJ-CX-0001. State prosecutors and courts in 40 of the 75 largest counties were asked to participate in a pilot study examining how domestic violence (DV) cases are handled by the justice system. These counties were identified because they had participated in the State Court Processing Statistics, 2002 data collection, which collected case processing information on a sample of felony cases filed in state courts. Of the counties asked to participate in the study on domestic violence case processing, prosecutors and courts in the following 16 counties agreed:

\begin{tabular}{l|l}
\hline State & \multicolumn{1}{|c}{ County } \\
\hline Arizona & Pima \\
\hline California & $\begin{array}{l}\text { Alameda, Orange, Riverside, San Diego, Santa } \\
\text { Clara }\end{array}$ \\
\hline Florida & Dade, Palm Beach, Pinellas \\
\hline Georgia & Fulton \\
\hline Indiana & Marion \\
\hline Ohio & Franklin \\
\hline Tennessee & Shelby \\
\hline Texas & El Paso, Tarrant, Travis \\
\hline
\end{tabular}

Note: See appendix table 2 for the distribution of intimate partner violence cases by participating jurisdiction.

In each of the 16 counties, the prosecutor's office or the court clerk's office compiled a list of domestic violence cases filed in state court in May 2002. In 7 of the 16 counties, the case list was provided by a specialized DV prosecution unit. In the remaining 9 counties, the case list was generated by examining all cases opened in May 2002 to identify those that contained a domestic violence charge.
Domestic violence was defined as "intentional physical violence committed, attempted, or threatened between family members, intimate partners, or household cohabitants." Family members included persons related by blood or marriage. Intimate partners included marital relations, such as spouses, ex-spouses, and common-law spouses, as well as boyfriends or girlfriends, present or past. A case was classified as domestic violence if 1) it met the above definition, based on the relationship of the victim to the defendant, and 2) the underlying charge was for a violent offense or for a violation of a protection order. For a small number of cases, the prosecutor's files either could not be located or were not available for legal reasons, such as the case was still pending at the time of data collection or the case file was sealed to comply with statutory regulations.

State prosecutors and courts in the participating counties provided data on 4,562 defendants whose most serious arrest charge was a domestic violence offense (DV). Approximately $83 \%$ of the 4,562 identified DV cases, or 3,750 cases, involved a victim and defendant who were intimate partners. See appendix table 2 for the distribution of intimate partner violence cases by participating jurisdiction.

\section{Data sources}

Data on the 3,750 intimate partner violence cases (IPV) are based on the information contained in both prosecutor files and court records. Prosecutor files were the primary source of information on characteristics of the violent incident, including victim and defendant demographics, measures of the severity of the incident, such as weapon use by the defendant and whether the victim was injured, history of abuse between the victim and defendant, and the presence of witnesses to the incident. Court records 
were the primary source of information on case processing data, such as charges filed against the defendant, adjudication outcomes, and sentencing information. Case processing data were documented for one year following the defendant's first appearance in court in May 2002.

This study also captured information about the general case screening practices employed by prosecutors at the time of the data collection in the 16 participating jurisdictions. Prosecutors in 9 of the 16 jurisdictions indicated that cases were reviewed prior to a defendant's initial court appearance to determine whether the case would be pursued for prosecution. In the remaining seven jurisdictions, case review by prosecutors did not occur until after the case was filed with the court. State law in some of the seven jurisdictions mandates case filing upon arrest. Counties in which prosecutors review cases after initial filing have a rate of dismissal (49\%) that is nearly two and a half times greater than the comparable rate in counties that screen prior to court filing (21\%) (table 17).

\section{Multivariate statistical techniques}

This report analyzes the characteristics and outcomes of intimate partner violence cases through both bivariate and multivariate statistical techniques. While bivariate statistics provide a descriptive overview of intimate partner violence case characteristics and outcomes, multivariate analysis can help identify the impacts that specific case characteristics, such as presence of a witness, evidence obtained, and prior history of violence between victim and defendant have on the probability of a conviction. A logistic regression model was used to estimate the impact of case characteristics on the probability of a conviction.

Also included in the model were a defendant's race and gender, whether the defendant was charged with a felony or misdemeanor, and individual county-level effects. To account for county-level effects, a model predicting the probability of conviction was first run at the county level, and the residuals produced from that analysis were added to the main individuallevel model. Incorporating the estimates of the residuals, which were statistically significant,

\section{Table 17.}

Adjudication outcome in intimate partner violence cases in 16 large counties, by prosecutor screening practice, May 2002

\begin{tabular}{l|c|c}
\hline \multirow{2}{*}{ Adjudication outcome } & \multicolumn{2}{|c}{ Prosecutors screened cases- } \\
\cline { 2 - 3 } Total & $\begin{array}{l}\text { Prior to defendant's initial } \\
\text { appearance in court }\end{array}$ & $\begin{array}{l}\text { After defendant's initial } \\
\text { appearance in court }\end{array}$ \\
\hline Conviction & $\mathbf{1 0 0 \%}$ & $\mathbf{1 0 0 \%}$ \\
\hline Dismissal/nolle prosequi/acquittal & 71.5 & 37.0 \\
\hline Pretrial diversion/deferred adjudication & 20.9 & 49.2 \\
\hline Case pending* & 5.1 & 12.8 \\
\hline
\end{tabular}

Note: Adjudication outcomes available for $99.4 \%$ of all intimate partner violence cases. ${ }^{\star}$ As of May 31, 2003. 
into the model allowed for the ability to isolate the impact of case characteristics on the likelihood of a conviction while accounting for the independent county effects.

The findings from this study are based on a complete enumeration of the cases processed in the month of May in the 16 counties agreeing to participate in the study. Given this approach to data collection, BJS did not compute confidence intervals for the estimates, nor did BJS conduct statistical significance tests to compare the estimates across different subgroups and to evaluate the logistic regression analysis. Findings in this report may not be representative of those that would have been obtained by examining cases processed throughout the entire year, or from other counties that did not participate in the study.

The logistic regression analyses were limited and intended to reflect the effects of selected factors that were available in the data collected. Other factors could potentially be related to the probability of conviction. For example, information about whether the defendant was arrested at the scene of the crime and the defendant's prior criminal history was unavailable. If data on these variables were available, the logistic regression results could be altered.

\section{Appendix Table 1.}

Relationship of victim to defendant in domestic violence cases in 16 large counties, by charge type, May 2002

\begin{tabular}{|c|c|c|c|}
\hline \multirow[b]{2}{*}{ Victim was defendant's- } & \multirow[b]{2}{*}{ All cases } & \multicolumn{2}{|c|}{ Percent of domestic violence defendants charged with a- } \\
\hline & & Felony & Misdemeanor \\
\hline Total & $100 \%$ & $100 \%$ & $100 \%$ \\
\hline Intimate partner & 83.4 & 74.6 & 85.7 \\
\hline Spouse & 33.3 & 26.3 & 35.1 \\
\hline Boyfriend or girlfriend & 50.1 & 48.3 & 50.6 \\
\hline Non-intimate family member & 15.5 & 23.1 & 13.5 \\
\hline Parent or guardian & 3.1 & 3.8 & 2.9 \\
\hline Son or daughter & 6.2 & 11.7 & 4.8 \\
\hline Sibling & 3.5 & 2.8 & 3.7 \\
\hline Other family member & 2.7 & 4.8 & 2.1 \\
\hline Non-intimate household member & 1.1 & 2.3 & 0.8 \\
\hline Total cases ${ }^{\star}$ & 4,562 & 940 & 3,622 \\
\hline
\end{tabular}

\section{Appendix Table 2.}

Number of defendants in intimate partner violence cases in 16 large counties, by county, state, and charge type, May 2002

\begin{tabular}{l|c|c|c}
\hline \multirow{2}{*}{ County and State } & & \multicolumn{2}{c}{ Number of defendants charged with a- } \\
\hline Pima, AZ & All cases & Felony & Misdemeanor \\
\hline Alameda, CA & 41 & 12 & 131 \\
\hline Orange, CA & 139 & 8 & 274 \\
\hline Riverside, CA & 298 & 24 & 207 \\
\hline San Diego, CA & 317 & 110 & 232 \\
\hline Santa Clara, CA & 301 & 69 & 219 \\
\hline Dade, FL & 276 & 57 & 309 \\
\hline Palm Beach, FL & 392 & 83 & 91 \\
\hline Pinellas, FL & 117 & 26 & 206 \\
\hline Fulton, GA & 299 & 93 & 104 \\
\hline Marion, IN & 123 & 19 & 213 \\
\hline Franklin, OH & 298 & 85 & 356 \\
\hline Shelby, TN & 375 & 19 & 153 \\
\hline El Paso, TX & 177 & 24 & 203 \\
\hline Tarrant, TX & 237 & 34 & 147 \\
\hline Travis, TX & 147 & 0 & 183 \\
\hline Total & 213 & 30 & $\mathbf{3 0 5 7}$ \\
\hline
\end{tabular}


Washington, DC 20531

Official Business

Penalty for Private Use $\$ 300$

The Bureau of Justice Statistics is the statistical agency of the U.S. Department of Justice. Michael D. Sinclair is acting director.

This Special Report was written by Erica L. Smith and Donald J. Farole, Jr., Ph.D.

Sean P. Rosenmerkel verified the report.

Georgette Walsh and Jill Duncan edited the report, Tina Dorsey produced the report, and Jayne Robinson prepared the report for final printing, under the supervision of Doris J. James.

October 2009, NCJ 228193

This report in portable document format and in ASCII and its related statistical data and tables are available at the BJS World Wide Web Internet site: <http://www.ojp.usdoj.gov/bjs/abstract/pipvcluc.htm>.

Office of Justice Programs

Innovation • Partnerships • Safer Neighborhoods

http://www.ojp.usdoj.gov 